\title{
The Interplay between Calcium and Strontium in Chinese Cabbage under Normal and Low Calcium Conditions
}

\author{
Nianwei Qiu, Li Tian, Xifeng Yan, Haoyu Dong, and Mengyu Zhang \\ College of Life Sciences, Qufu Normal University, Qufu, Shandong \\ 273165, China
}

\section{Guoliang Han}

Shandong Provincial Key Laboratory of Plant Stress, Shandong Normal University, Jinan 250014, China

\section{Feng Zhou \\ School of Food Science, Nanjing Xiaozhuang University, Nanjing 211171, China}

Additional index words. calcium deficiency, growth, metabolism, photosynthesis, strontium toxicity

\begin{abstract}
The structure and chemical properties of strontium and calcium are similar. To study the interplay between calcium and strontium in plants, different concentrations of $\operatorname{SrCl}_{2}\left(0,1,4\right.$, and $\left.10 \mathrm{mmol} \cdot \mathrm{L}^{-1}\right)$ were added to the Hoagland nutrient solution with 4 mmol $\cdot \mathrm{L}^{-1} \mathrm{Ca}^{2+}$ (normal level $\mathrm{Ca}^{2+}$ ) or $0.4 \mathrm{mmol} \cdot \mathrm{L}^{-1} \mathrm{Ca}^{2+}\left(\right.$ low-level $\left.\mathrm{Ca}^{2+}\right)$, which were used to cultivate Chinese cabbage seedlings. Under the low-level calcium condition, strontium not only did not promote the growth of Chinese cabbage but showed more severe toxicity compared with that under the normal calcium condition. Under normal calcium condition, although the growth of Chinese cabbage was significantly inhibited by 4 mmol $\cdot \mathrm{L}^{-1}$ strontium, strontium did not show significant toxicity. However, under the low-level calcium condition, $1 \mathrm{mmol} \cdot \mathrm{L}^{-1}$ strontium caused a significant decline of plant biomass and photosynthetic activity. $\mathrm{Sr}^{2+}$ showed a competitive inhibitory effect on the absorption of $\mathrm{Ca}^{2+}$, and strontium was more easily absorbed by Chinese cabbage. Under the low-level calcium condition, strontium aggravated the inhibition of calcium absorption. The inhibitory effect of strontium on plant growth was significantly related to the calcium content in Chinese cabbage. Strontium cannot replace the function of calcium in plants under calcium-deficient conditions.
\end{abstract}

Strontium (Sr, atomic No. 38) is ubiquitous in nature and is estimated to be the 15 th most abundant element on earth. The average content of strontium in the earth's crust is $\approx 0.034 \%$. Given the extreme reactivity of strontium, its natural occurrence is only in compound forms with other elements (Gupta et al., 2018a). The chief minerals containing strontium are celestite $\left(\mathrm{SrSO}_{4}\right)$ and strontianite $\left(\mathrm{SrCO}_{3}\right)$. Soluble strontium mainly exists in the form of $\mathrm{Sr}^{2+}$ (Sasmaz and Sasmaz, 2009).

Strontium is important for human health and is one of the 14 essential trace elements for humans. In particular, it has been widely used as an antiosteoporotic agent (Höllriegl

Received for publication 18 Mar. 2021. Accepted for publication 4 May 2021.

Published online 18 June 2021

This work was funded by the Open Fund of Shandong Provincial Key Laboratory of Plant Stress (Project No. KF201801) and the Natural Science Foundation of Shandong Province, China (ZR2020MC144).

N.Q. and L.T. contributed equally to this work.

F.Z. is the corresponding author. E-mail: zfibcas@163.com.

This is an open access article distributed under the CC BY-NC-ND license (https://creativecommons. org/licenses/by-nc-nd/4.0/) and München, 2011; Nielsen, 2004). However, in botanical studies, strontium has always been regarded as a pollutant. On one hand, radiostrontium (mainly ${ }^{90} \mathrm{Sr}$ ) is the main radiation pollutant in nuclear accidents, which can pose adverse effects on living things (Amano et al., 2016). On the other hand, stable strontium (mainly ${ }^{88} \mathrm{Sr}$ ) at high concentrations in soil and water released from strontium minerals is harmful to the environment (Guillén, 2018). Phytoremediation is a promising approach to eliminate strontium pollution. Therefore, absorption, transport, and phytoremediation of strontium have become a hotspot in current plant research.

Strontium and calcium belong to group II of the periodic table, which share similar chemical properties. The ionic radius of $\mathrm{Sr}^{2+}$ and $\mathrm{Ca}^{2+}$ are 2.00 and $1.80 \AA$, respectively (Crystalmaker, n.d.). Yeast cells cannot discriminate $\mathrm{Ca}^{2+}$ and $\mathrm{Sr}^{2+}$ under experimental conditions (Heuck et al., 2010). The $\mathrm{Ca}^{2+}$ channels on the plasma membrane of wheat roots have the same permeability to $\mathrm{Ca}^{2+}$ and $\mathrm{Sr}^{2+}$ (Piñeros and Tester, 1995). In maize plants, the absorption efficiency of strontium is significantly greater than that of calcium (Moyen and Roblin, 2010). $\mathrm{Sr}^{2+}$ at high concentrations can inhibit the absorption of $\mathrm{Ca}^{2+}$ because these two ions compete for the same receptor sites on biological membranes (Gupta et al., 2018b). Similar to calcium, strontium is mainly absorbed and accumulated in the cell wall $(>50 \%)$. After entering the cell, strontium can replace calcium and interfere with the function of the cell (Anupama et al., 2016). Therefore, strontium at high concentrations has inhibitive effects on plants.

Although strontium is not an essential nutrient element for plants, we have recently confirmed that strontium at low concentrations can promote the growth of Chinese cabbage (Brassica rapa L. ssp. Pekinensis) seedlings (Zhang et al., 2020). This phenomenon was also observed in other plants (Chen et al., 2012; Kartosentono et al., 2001; Li et al., 2006; Moyen and Roblin, 2013; Ozgen et al., 2011; Sowa et al., 2014). However, only a few references mention this phenomenon, and the concentration range of strontium beneficial to plants is $\approx 0.1$ to $1.5 \mathrm{mmol} \cdot \mathrm{L}^{-1}$ (Burger and Lichtscheidl, 2019; Ozgen et al., 2011; Sowa et al., 2014). The mechanism by which low-concentration strontium promotes plant growth may be related to the interplay between calcium and strontium. To explore the relationship between calcium and strontium in plants, different concentrations of $\mathrm{SrCl}_{2}$ were added to the Hoagland nutrient solution (with normal-level $\mathrm{Ca}^{2+}$ or lowlevel $\mathrm{Ca}^{2+}$ ) to analyze whether strontium can compensate for the function of calcium under calcium-deficient conditions.

\section{Materials and Methods}

Plant culture. The full and uniform seeds of Chinese cabbage (Brassica rapa L. ssp. Pekinensis, 'Qingmaye') were provided by Weifang Seed Co., Ltd., and planted in moist sand. The sand was irrigated with a full modified No. 2 Hoagland nutrient solution ( $\mathrm{pH}$ 6.0, containing $4 \mathrm{mmol} \cdot \mathrm{L}^{-1} \mathrm{Ca}^{2+}$ ). The seedlings were cultured in a phytotron with the illumination of $300 \mu \mathrm{mol} \cdot \mathrm{m}^{-2} \cdot \mathrm{s}^{-1}$ provided by white LED lamps, 14/10-h light/dark photoperiod, 20 to $22{ }^{\circ} \mathrm{C}$, and $50 \%$ relative humidity.

Treatments. Six uniform seedlings with three leaves were transplanted into a white porcelain pot (inner diameter: $13 \mathrm{~cm}$; depth: $16 \mathrm{~cm}$ ), which were filled with $2 \mathrm{~L}$ modified Hoagland solution (a Ca-deprived Hoagland solution). Two concentrations of $\mathrm{Ca}\left(\mathrm{NO}_{3}\right)_{2}\left[0.4 \mathrm{mmol} \cdot \mathrm{L}^{-1}\right.$ (low-level $\mathrm{Ca}^{2+},-\mathrm{Ca}$ ) or $4 \mathrm{mmol} \cdot \mathrm{L}^{-1} \mathrm{Ca}\left(\mathrm{NO}_{3}\right)_{2}$ (normal-level $\mathrm{Ca}^{2+},+\mathrm{Ca}$ )], and different concentrations of strontium chloride $(0,1.0,4.0$, and $10.0 \mathrm{mmol} \cdot \mathrm{L}^{-1}{ }^{88} \mathrm{SrCl}_{2}$ ) were dissolved in the modified Hoagland solution, respectively. We added $6 \mathrm{mmol} \cdot \mathrm{L}^{-1} \mathrm{NaNO}_{3}$ to the low-level $\mathrm{Ca}^{2+}$ solution to ensure the same amount of nitrogen element in $+\mathrm{Ca}$ and $-\mathrm{Ca}$ solution. The $\mathrm{pH}$ value of each treatment solution was adjusted to 6.0 for calcium-strontium treatment. The solutions were renewed every $2 \mathrm{~d}$. Each treatment cultivated 10 pots of Chinese cabbage seedlings. After a 28-d exposure to different concentrations of $\mathrm{Sr}^{2+}$ and $\mathrm{Ca}^{2+}$, the seedlings were harvested for the measurement of the physiological indexes. The $0 \mathrm{mmol} \cdot \mathrm{L}^{-1}$ strontium treatment group was used as the control group under both $+\mathrm{Ca}$ condition and $-\mathrm{Ca}$ conditions. 
Measurements. The growth rate was expressed in terms of relative growth, with the original average fresh weight of the whole plant $\left(\mathrm{FW}_{\mathrm{o}}\right)$ before the treatment being set as $100 \%$. On the day of treatment, 10 hydroponic seedlings with consistent growth were randomly selected to weigh the fresh weight of the whole plant, and take their mean as $\mathrm{FW}_{\mathrm{o}}$. The remaining seedlings were treated with different concentrations of calcium and strontium. The relative fresh weight (RFW) was equal to the fresh weight after a 28-d treatment $\left(\mathrm{FW}_{\mathrm{t}}\right)$ divided by $\mathrm{FW}_{\mathrm{o}}$. The leaf number on the individual plant was the average number of unfolded leaves per seedling after the 28-d treatment. Ten replicates were conducted in the measurement of RFW and leaf number.

The soluble protein content in leaves was measured by Coomassie brilliant blue method, using bovine albumin for calibration. The chlorophyll $(\mathrm{Chl})$ in the biggest functional leaves was extracted with $80 \%$ acetone at $4{ }^{\circ} \mathrm{C}$, and the absorbance was measured at $646.6 \mathrm{~nm}$ and $663.6 \mathrm{~nm}$ for the calculation of the chlorophyll content (Porra, 2002).

The leaves were rinsed with deionized water before the measurement of the plasma membrane permeability, which is defined as relative conductivity (\%) and measured by a conductivity meter, which was calculated as primary conductivity/total conductivity $\times$ $100 \%$ (Sun et al., 2018). The peroxidation degree of membrane lipid was quantified by the production of malondialdehyde (MDA). MDA was extracted with $10 \%$ trichloroacetic acid (Hodges et al., 1999).

The photosynthetic activity of Chinese cabbage leaves was measured by a plant efficiency analyzer (PEA; Hansatech Instrument Ltd., UK) and defined with the maximum quantum yield $\left(F_{\mathrm{v}} / F_{\mathrm{m}}\right)$ and performance index $(P I)$ of photosystem II (PSII) (Stirbet and Govindjee, 2011). The seedlings were placed in the dark for $1 \mathrm{~h}$ before measurement.

For the measurement of the $\mathrm{Ca}^{2+}$ and $\mathrm{Sr}^{2+}$ contents in the leaves, $0.5 \mathrm{~g}$ dried leaves were homogenized and then digested with $\mathrm{HClO}_{4}$ :
$\mathrm{HNO}_{3}(1: 4, \mathrm{v} / \mathrm{v})$ for $5 \mathrm{~h}$ in quartz glass tubes. After the digested samples were evaporated to dryness, the residues were dissolved with deionized water. The contents of $\mathrm{Ca}^{2+}$ and $\mathrm{Sr}^{2+}$ were determined by an Agilent 7700 ICP-MS (Agilent Technologies Inc. Santa Clara, CA).

Statistical analyses. Statistical analyses for different $\mathrm{Ca}-\mathrm{Sr}$ treatments were performed by two-way analysis of variance and SSR tests (shortest significant ranges). Different superscript letters in the figures denote significant differences $(P<0.05)$ between every two CaSr treatments. All statistical analyses were performed with SPSS 17.0 software.

\section{Results}

Effects of calcium and strontium on plant growth. Calcium is an essential element for plant growth. The seedlings of Chinese cabbage are sensitive to calcium deficiency. After a 28-d exposure to normal-level calcium $\left(4 \mathrm{mmol} \cdot \mathrm{L}^{-1} \mathrm{Ca}^{2+},+\mathrm{Ca}\right)$, the RFW per Chinese cabbage seedling increased to 8.28 times of that before the treatment, whereas it was only 3.45 times under the low-level calcium condition $\left(0.4 \mathrm{mmol} \cdot \mathrm{L}^{-1} \mathrm{Ca}^{2+},-\mathrm{Ca}\right)$ (Fig. 1A). Under the $+\mathrm{Ca}$ condition, the addition of $1 \mathrm{mmol} \cdot \mathrm{L}^{-1}$ strontium had no significant effect on the growth of Chinese cabbage. However, 4 and $10 \mathrm{mmol} \cdot \mathrm{L}^{-1} \mathrm{SrCl}_{2}$ significantly decreased the RFW, which were $53.3 \%$ and $33.6 \%$ of that of the control group, respectively. Although calcium and strontium are structurally similar, adding strontium in the - Ca solution could not alleviate the growth inhibition caused by calcium deficiency. On the contrary, the addition of strontium aggravated the inhibition of plant growth. Under the - Ca condition, the RFW of the 1,4 , and 10 $\mathrm{mmol} \cdot \mathrm{L}^{-1} \mathrm{SrCl}_{2}$-treatment was $2.47,1.67$, and 0.95 , respectively. Chinese cabbage seedlings stopped growing and withered under the condition of $-\mathrm{Ca}$ and $10 \mathrm{mmol} \cdot \mathrm{L}^{-1} \mathrm{SrCl}_{2}$ (Fig. 1A). The interplay effects of calcium and strontium could also be detected by the leaf number per seedling. Calcium deficiency significantly reduced the leaf number per seedlings. Adding 4 and $10 \mathrm{mmol} \cdot \mathrm{L}^{-1} \mathrm{SrCl}_{2}$ also reduced the leaf number per seedlings under the $+\mathrm{Ca}$ condition. The superposition of the two conditions resulted in fewer leaves per seedlings (Fig. 1B). The results in Fig. 1 show that strontium could not replace the function of calcium in plants. High concentration of strontium is an inhibitory factor to plants.

Effects of calcium and strontium on metabolism. Under the $+\mathrm{Ca}$ condition, although 4 and $10 \mathrm{mmol} \cdot \mathrm{L}^{-1}$ strontium inhibited the growth of Chinese cabbage seedlings, the protein and chlorophyll contents in the leaves did not decrease, and the protein content was even higher than that of the control group. Therefore, strontium had no significant toxicity to plant cell metabolism under the $+\mathrm{Ca}$ condition. Under the $-\mathrm{Ca}$ condition, 4 and 10 $\mathrm{mmol} \cdot \mathrm{L}^{-1}$ strontium significantly reduced the protein and chlorophyll contents of the leaves, showing toxicity to plant cell metabolism (Fig. 2A and B). It is speculated that calcium and strontium have an antagonistic effect. High concentrations of strontium had significant toxicity to plant metabolism under the $-\mathrm{Ca}$ condition. Increasing calcium could relieve the toxicity of strontium to plants.

Effects of calcium and strontium on biological membranes. The low calcium treatment $(-\mathrm{Ca})$ alone did not affect the stability of the plasma membranes. Compared with $+\mathrm{Ca}$ condition, the plasma membrane permeability and MDA content of Chinese cabbage leaves did not change significantly (Fig. 3A and B). Under the $+\mathrm{Ca}$ condition, the $10 \mathrm{mmol} \cdot \mathrm{L}^{-1}$ $\mathrm{SrCl}_{2}$-treatment significantly increased plasma membrane permeability and MDA content, and 1 and $4 \mathrm{mmol} \cdot \mathrm{L}^{-1} \mathrm{SrCl}_{2}$ treatments had no effects on these two indicators. Under the $-\mathrm{Ca}$ condition, with the increase of the strontium concentration, plasma membrane permeability gradually increased, and the degree of membrane lipid peroxidation (MDA content) was enhanced significantly, showing obvious membrane damage (Fig. 3A and B). Under the
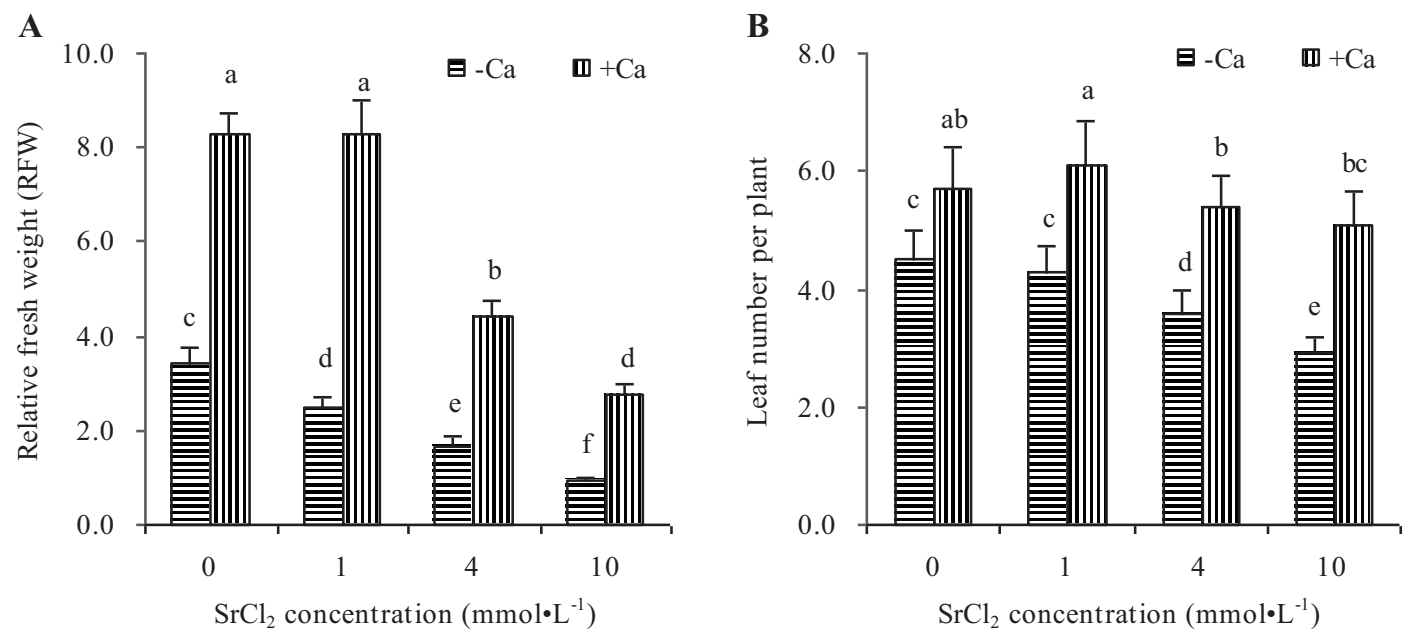

Fig. 1. The relative fresh weight $(\mathrm{RFW})(\mathbf{A})$ and the leaf number per plant $(\mathbf{B})$ of Chinese cabbage seedlings treated with different concentrations of SrCl 2 (0, 1,4 , and $\left.10 \mathrm{mmol} \cdot \mathrm{L}^{-1}\right)$ and $\mathrm{Ca}\left(\mathrm{NO}_{3}\right)_{2}\left(\right.$ low-level $\mathrm{Ca}^{2+},-\mathrm{Ca}$; normal-level $\mathrm{Ca}^{2+}$, $\left.+\mathrm{Ca}\right)$ for $28 \mathrm{~d}$. The bars are means $\pm \mathrm{SD}(\mathrm{n}=10)$. Means marked with different letters indicate significant difference $(P<0.05)$. 
A

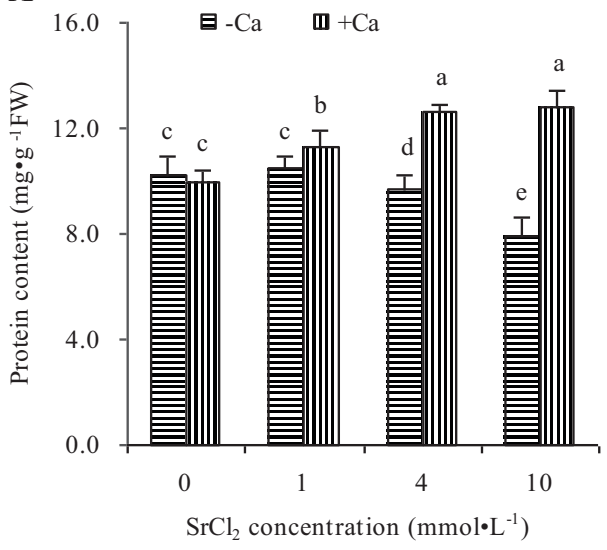

B

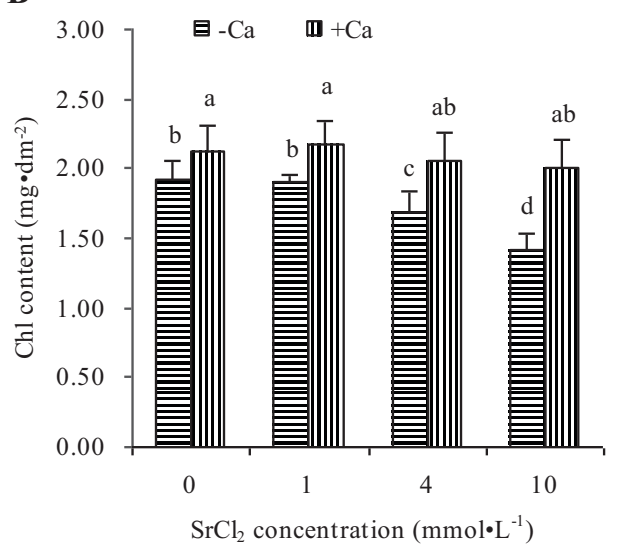

Fig. 2. The leaf protein content (A) and chlorophyll (Chl) content $(\mathbf{B})$ of Chinese cabbage under different concentrations of calcium and strontium. The bars are means \pm SD $(n=6)$. Means marked with different letters indicate significant difference $(P<0.05)$.

calcium-deficient condition, strontium showed higher membrane toxicity.

Effects of calcium and strontium on photosynthetic activity. Chlorophyll a fluorescence can be used to detect the changes of photosynthetic function of plants. Among the fluorescence parameters, $F_{\mathrm{v}} / F_{\mathrm{m}}$ and $P I$ are the most commonly used. The $F_{\mathrm{v}} / F_{\mathrm{m}}$ value of healthy plant leaves is $\approx 0.832$ (Björkman and Demmig, 1987). Under the $+\mathrm{Ca}$ condition, the treatments of 1,4 , and $10 \mathrm{mmol} \cdot \mathrm{L}^{-1} \mathrm{SrCl}_{2}$ only slightly reduced the $F_{\mathrm{v}} / F_{\mathrm{m}}$ value of Chinese cabbage leaves by $0.1 \%, 1.6 \%$, and $2.6 \%$ compared with that of the control group, respectively. The calcium-deficient treatment alone slightly decreased the $F_{\mathrm{v}} / F_{\mathrm{m}}$ as well. Under the - Ca condition, the $F_{\mathrm{v}} / F_{\mathrm{m}}$ value of Chinese cabbage leaves treated with 1,4 , and $10 \mathrm{mmol} \cdot \mathrm{L}^{-1}$ $\mathrm{SrCl}_{2}$ were dropped by $2.8 \%, 8.4 \%$, and $15.3 \%$, respectively, compared with that of the control group (Fig. 4A). PI is more sensitive than $F_{\mathrm{v}} / F_{\mathrm{m}}$. In the presence of normal calcium, the treatments of 4 and $10 \mathrm{mmol} \cdot \mathrm{L}^{-1} \mathrm{SrCl}_{2}$ reduced the $P I$ value by $11.1 \%$ and $19.6 \%$, respectively (Fig. 4B). Under the $-\mathrm{Ca}$ condition, the treatments of 1,4 , and $10 \mathrm{mmol} \cdot \mathrm{L}^{-1}$ $\mathrm{SrCl}_{2}$ reduced the $P I$ value by $15.7 \%, 61.4 \%$, and $76.6 \%$, respectively (Fig. 4B). These two fluorescence parameters demonstrated that 4 and $10 \mathrm{mmol} \cdot \mathrm{L}^{-1} \quad \mathrm{SrCl}_{2}$ could significantly affect the photosynthetic light reaction regardless of $+\mathrm{Ca}$ or $-\mathrm{Ca}$ conditions, and their inhibitory effects were more obvious under the $-\mathrm{Ca}$ condition.

The absorption of calcium and strontium. Under the - Ca condition, the calcium contents in Chinese cabbage leaves were lower than that under the $+\mathrm{Ca}$ condition (Fig. 4A). However, the absorption of calcium was not proportional to the calcium level in the medium. Under the 0.4 and $4 \mathrm{mmol} \cdot \mathrm{L}^{-1} \mathrm{Ca}^{2+}$ conditions $\left(0 \mathrm{mmol} \cdot \mathrm{L}^{-1} \mathrm{SrCl}_{2}\right)$, the calcium contents in Chinese cabbage leaves were 7.43 and $22.43 \mathrm{mg} \cdot \mathrm{g}^{-1} \mathrm{DW}$, respectively. With the increase of the strontium concentration, the calcium content of leaves gradually decreased. In the presence of $4 \mathrm{mmol} \cdot \mathrm{L}^{-1} \mathrm{Ca}^{2+}$, the calcium content in the leaves treated by 1,4 , and $10 \mathrm{mmol} \cdot \mathrm{L}^{-1} \quad \mathrm{SrCl}_{2}$ decreased to $97.0 \%$, $44.7 \%$, and $33.2 \%$ of the control group, respectively. In the presence of $0.4 \mathrm{mmol} \cdot \mathrm{L}^{-1}$ $\mathrm{Ca}^{2+}$, the calcium content in the leaves treated by 1,4 , and $10 \mathrm{mmol} \cdot \mathrm{L}^{-1} \mathrm{SrCl}_{2}$ decreased to $80.6 \%, 29.3 \%$, and $20.7 \%$ of the control group, respectively. Under the -Ca condition, strontium inhibited calcium absorption more significantly than that under the $+\mathrm{Ca}$ condition. Under the $-\mathrm{Ca}$ condition, the absorption of strontium was significantly greater than that under the $+\mathrm{Ca}$ condition (Fig. 4B). The greater the ratio of exogenous strontium to calcium, the more significant the inhibition of calcium absorption observed. These results indicate that the absorption of strontium and calcium compete against each other.

\section{Discussion}

The content of strontium in the soil is $\approx 340 \mathrm{mg} \cdot \mathrm{kg}^{-1}$ on average, of which the soluble strontium is only $\approx 0.2 \mathrm{mg} \cdot \mathrm{kg}^{-1}$. The average content of soluble calcium in soil is as high as $400 \mathrm{mg} \cdot \mathrm{kg}^{-1}$, which is $\approx 2000$ times of the content of soluble strontium (Ermakov et al., 2020). It is difficult to observe the interplay between calcium and strontium under normal circumstances. In recent years, with the continuous exploitation of strontium ore and the gradual expansion of the use of strontium, strontium pollution has become a serious concern (Burger and Lichtscheidl, 2019). Many studies have begun to focus on plant responses to high levels of strontium pollution. Because calcium and strontium have similar
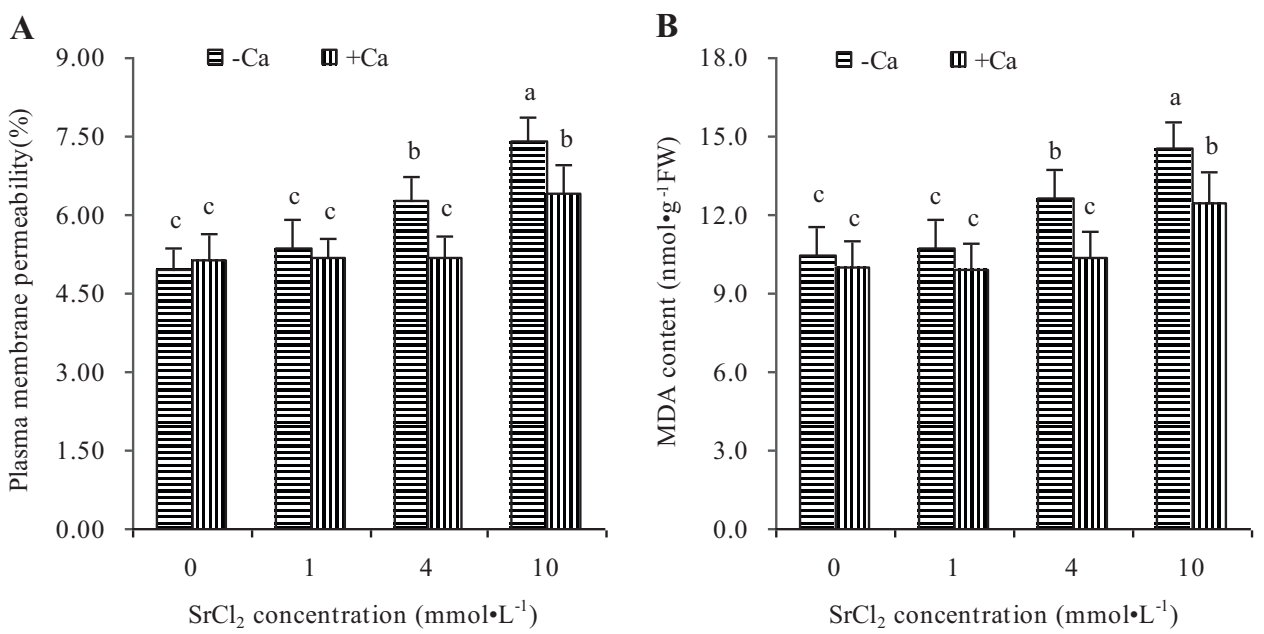

Fig. 3. The plasma membrane permeability (A) and malondialdehyde (MDA) content (B) of Chinese cabbage leaves under different concentrations of calcium and strontium. The bars are means $\pm \mathrm{SD}(\mathrm{n}=6)$. Means marked with different letters indicate significant difference $(P<0.05)$. 

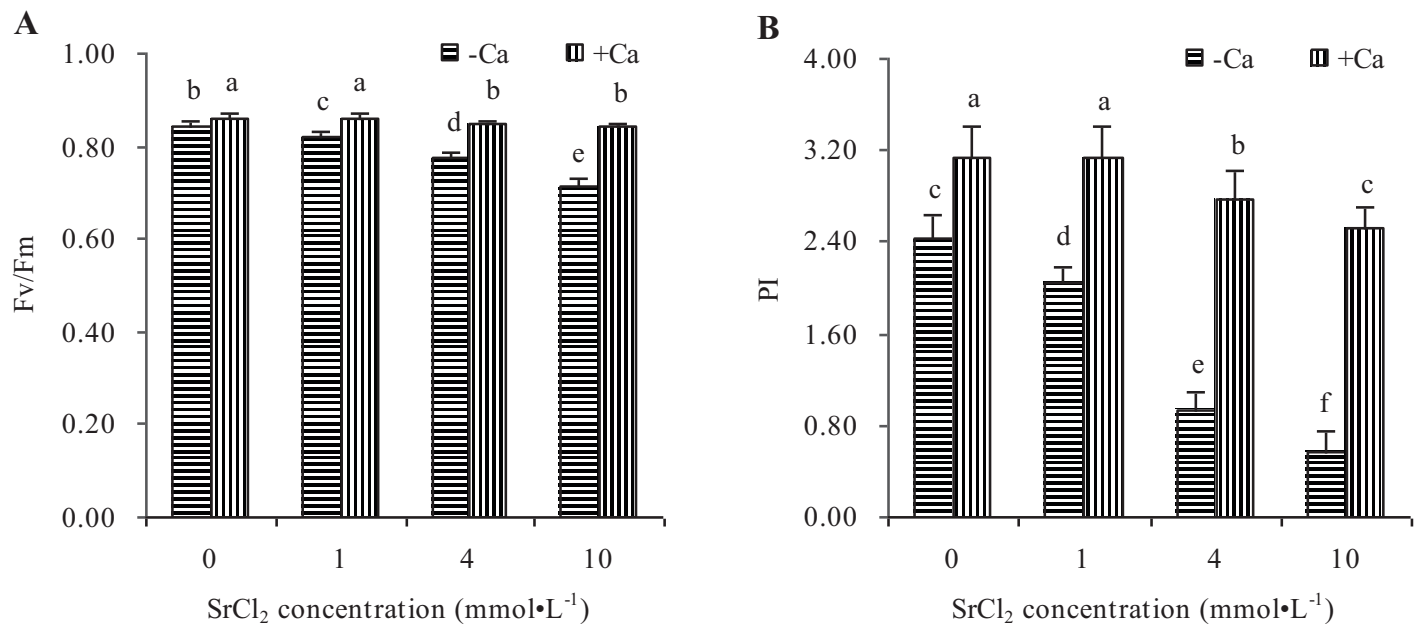

Fig. 4. The maximum quantum yield $\left(F_{\mathrm{v}} / F_{\mathrm{m}}\right)(\mathbf{A})$ and performance index $(P I)(\mathbf{B})$ of PSII of Chinese cabbage leaves under different concentrations of calcium and strontium. The bars are means \pm SD $(\mathrm{n}=10)$. Means marked with different letters indicate significant difference $(P<0.05)$.

ionic structures and chemical properties, high concentrations of strontium may replace the function of calcium in plants. It is unclear whether strontium and calcium are mutually antagonistic or complementary.

Under the $+\mathrm{Ca}$ condition, 1 to $10 \mathrm{mmol} \cdot \mathrm{L}^{-1}$ strontium was added to the culture medium of Chinese cabbage for $28 \mathrm{~d}$. It was found that the $1 \mathrm{mmol} \cdot \mathrm{L}^{-1}$ strontium treatment did not significantly affect plant growth or metabolic activity of Chinese cabbage. Compared with the control plants, the RFW and leaf number of Chinese cabbage seedlings did not change significantly (Fig. 1). The leaf chlorophyll content, photosynthetic activity, and plasma membrane stability had no significant changes either. Therefore, 1 $\mathrm{mmol} \cdot \mathrm{L}^{-1}$ strontium was not toxic to Chinese cabbage seedlings (Figs. 2 and 4). The 4 and 10 $\mathrm{mmol} \cdot \mathrm{L}^{-1}$ strontium treatments had a significant inhibitory effect on the growth of Chinese cabbage seedlings. The RFW and leaf number of Chinese cabbage seedlings were reduced, and the photosynthetic activity was slightly decreased (Figs. 1 and 4). The 4 and 10 $\mathrm{mmol} \cdot \mathrm{L}^{-1}$ strontium treatments also caused damage to the plasma membrane of the leaves (Fig. 3), which has also been observed in Spanish moss (Zheng et al., 2016). However, under the conditions of 4 and $10 \mathrm{mmol} \cdot \mathrm{L}^{-1}$ strontium, the leaf chlorophyll content of Chinese cabbage seedlings was almost unchanged, and the protein content increased. The 4 to $10 \mathrm{mmol} \cdot \mathrm{L}^{-1}$ strontium treatment mainly inhibited the growth of Chinese cabbage seedlings or showed slight peroxidation damage, which was similar to Amaranthus mangostanus (Wang et al., 2015). The phytotoxicity of strontium is different from the phytotoxicity of heavy metals such as $\mathrm{Cd}$ and $\mathrm{Hg}$, whose toxic concentration is at the $\mu \mathrm{mol} \cdot \mathrm{L}^{-1}$ level (Arif et al., 2019; Sytar et al., 2019). The concentration of strontium inhibiting plant growth is generally greater than $1.0 \mathrm{mmol} \cdot \mathrm{L}^{-1}$ (Burger and Lichtscheidl, 2019). Some studies have also found that low concentrations of strontium $\left(<1.5 \mathrm{mmol} \cdot \mathrm{L}^{-1}\right)$ can promote the growth of certain plants (Sowa et al., 2014; Zhang et al., 2020). The function of strontium in plants is unclear.
Due to the similar structure and properties of strontium and calcium, strontium can perform part of the functions of calcium in the photosystem II oxygen-evolving complex (Boussac et al., 2004; Ishida et al., 2008). We speculated that adding 1 to $10 \mathrm{mmol} \cdot \mathrm{L}^{-1}$ strontium under the $-\mathrm{Ca}$ condition might relieve the symptoms of calcium deficiency. The experimental results showed the opposite; the 1 to 10 $\mathrm{mmol} \cdot \mathrm{L}^{-1}$ strontium treatment significantly aggravated the symptoms of calcium deficiency. Compared with the control group ( 0 $\left.\mathrm{mmol} \cdot \mathrm{L}^{-1} \mathrm{Sr}^{2+}\right)$, the $1 \mathrm{mmol} \cdot \mathrm{L}^{-1}$ strontium treatment significantly reduced the RFW of Chinese cabbage under the $-\mathrm{Ca}$ condition (Fig. 1). In contrast to the $+\mathrm{Ca}$ condition, the protein content and chlorophyll content of Chinese cabbage leaves treated with 4 to $10 \mathrm{mmol} \cdot \mathrm{L}^{-1}$ strontium decreased significantly under the - Ca condition (Fig. 2). In addition, the 4 to 10 $\mathrm{mmol} \cdot \mathrm{L}^{-1}$ strontium treatment resulted in more significant membrane damage and lower photosynthetic efficiency under the - $\mathrm{Ca}$ condition (Figs. 3 and 4). Therefore, strontium cannot replace the role of calcium in plants.

Strontium exhibited greater toxicity to Chinese cabbage seedlings under the - Ca condition, which may be related to the inhibition of calcium absorption by strontium. Strontium can enter plant cells through calcium channels (Moyen and Roblin, 2013), which exhibit similar permeability to $\mathrm{Sr}^{2+}$ and $\mathrm{Ca}^{2+}$ (Piñeros and Tester, 1995). Therefore, there is an absorption competition between $\mathrm{Sr}^{2+}$ and $\mathrm{Ca}^{2+}$. Under the $+\mathrm{Ca}$ condition, Chinese cabbage seedlings could absorb relatively more $\mathrm{Ca}^{2+}$ than that under the $-\mathrm{Ca}$ condition, maintaining the calcium demand of plant cells (Fig. 5). Under the $-\mathrm{Ca}$ condition, the higher ratio of the external $\mathrm{Sr}^{2+} / \mathrm{Ca}^{2+}$ aggravated the inhibition of calcium absorption. A more significant phenomenon is that the RFW value of Chinese cabbage seedlings was not significantly correlated with the strontium content in their leaves $\left(r^{2}=\right.$ $0.4455, P>0.05)$ but was significantly correlated with their calcium content $\left(r^{2}=0.9901\right.$, $P<0.01)$ (Table 1). There is no significant correlation between the strontium content and
Table 1. Linear relationships between the relative fresh weight (RFW) value and $\mathrm{Ca}$ and $\mathrm{Sr}$ content in Chinese cabbage leaves of all treatments.

\begin{tabular}{lcl}
\hline $\begin{array}{l}\text { Related } \\
\text { variables }\end{array}$ & $\begin{array}{c}\text { Regression } \\
\text { equation }\end{array}$ & $R^{2}$ value \\
\hline $\begin{array}{c}\mathrm{RFW}(\mathrm{x}) \\
\text { and Ca }\end{array}$ & $y=2.837 x-1.614$ & 0.9901 \\
$\mathrm{RFW}(\mathrm{x})$ & $y=-3.278 x+29.296$ & 0.4455 \\
and Sr & & \\
\hline
\end{tabular}

The relevant data comes from Figs. 1A and 5.

chlorophyll content either (Garty et al., 1985). On the basis of these results, it can be inferred that the strontium content of leaves was not a key factor affecting plant growth. The growth of Chinese cabbage seedlings inhibited by the high concentration of external $\mathrm{Sr}^{2+}$ is related to the decreased $\mathrm{Ca}^{2+}$ content in plants. Hence, the toxicity of strontium at high concentrations is similar to that of calcium deficiency in plants (Jiang et al., 2018). Calcium deficiency first affects cell membranes and cell walls. Calcium pectate is the main component of the cell wall. Both high concentrations of strontium and calcium deficiency can lead to the decrease of calcium pectate, which affects the structure of the cell walls and enhances the permeability of the plasma membranes. When the concentration of strontium is too high, it may also cause chlorotic effects, reduce the content of chlorophyll and protein, and induce oxidative stress (Burger and Lichtscheidl, 2019).

\section{Conclusions}

In summary, our results indicate that $\mathrm{Sr}^{2+}$ had a competitive inhibitory effect on $\mathrm{Ca}^{2+}$ absorption. Strontium was more easily absorbed by Chinese cabbage. The 4 to $10 \mathrm{mmol} \cdot \mathrm{L}^{-1}$ strontium treatment significantly inhibited the absorption of calcium under the $+\mathrm{Ca}$ condition, whereas 1 to $10 \mathrm{mmol} \cdot \mathrm{L}^{-1}$ strontium aggravated the inhibition of calcium absorption under the $-\mathrm{Ca}$ condition. $\mathrm{Sr}^{2+}$ entering the cell was less toxic to plants and could compensate a few function of $\mathrm{Ca}^{2+}$ but could not fully replace calcium. Besides the functions in 
A

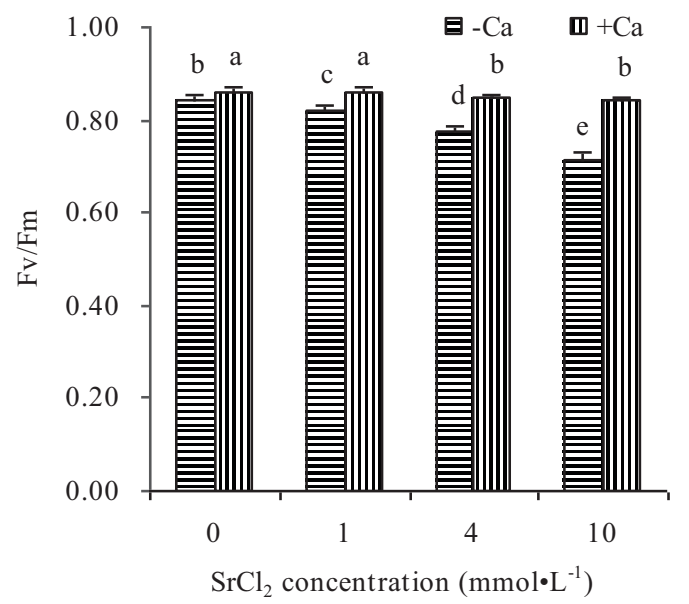

B

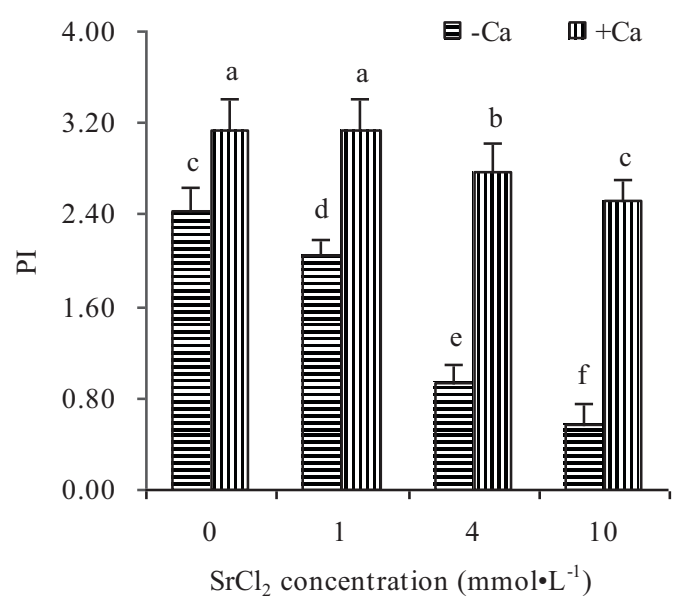

Fig. 5. Calcium content and strontium content in Chinese cabbage leaves under different concentrations of calcium and strontium. The bars are means \pm SD $(\mathrm{n}=5)$. Means marked with different letters indicate significant difference $(P<0.05)$.

oxygen-evolving complexes in vitro and cell walls (Anupama et al., 2016), there is no evidence that strontium can completely replace $\mathrm{Ca}^{2+}$ in regulating signaling pathways and other enzyme activities. The growth of Chinese cabbage seedlings was significantly correlated with the calcium content in plants, indicating that strontium inhibits the growth of Chinese cabbage seedlings mainly by inhibiting calcium absorption. These results are helpful in understanding the biological functions of strontium and its phytotoxicity mechanism.

\section{Literature Cited}

Amano, H., H. Sakamoto, N. Shiga, and K. Suzuki. 2016. Method for rapid screening analysis of Sr-90 in edible plant samples collected near Fukushima, Japan. Appl. Radiat. Isot. 112:131135, doi: https://doi.org/10.1016/j.apradiso. 2016.03.026

Anupama, M., K.K. Ashok, and J.N.L. Latha. 2016. Mechanism of strontium uptake and transport in Neurospora crassa. Eur. J. Pharm. Med. Res. 3:379-386. https://www.researchgate.net/ publication/322701220.

Arif, N., N.C. Sharma, V. Yadav, N. Ramawat, N.K. Dubey, D.K. Tripathi, D.K. Chauhan, and S. Sahi. 2019. Understanding heavy metal stress in a rice crop: Toxicity, tolerance mechanisms, and amelioration strategies. J. Plant Biol. 62:239-253, doi: https://doi.org/10.1007/s12374-019-0112-4.

Björkman, O. and B. Demmig. 1987. Photo yield of $\mathrm{O}_{2}$ evolution and chlorophyll fluorescence characteristics at $77 \mathrm{~K}$ among vascular plants of diverse origins. Planta 170:489-504, doi: https://doi.org/10.1007/BF00402983.

Boussac, A., F. Rappaport, P. Carrier, J.M. Verbavatz, R. Gobin, D. Kirilovsky, A.W. Rutherford, and M. Sugiura. 2004. Biosynthetic $\mathrm{Ca}^{2+} / \mathrm{Sr}^{2+}$ exchange in the photosystem II oxygen-evolving enzyme of Thermosynechococcus elongatus. J. Biochem. 279:22809-22819, doi: https://doi. org/10.1074/jbc.M401677200.

Burger, A. and I. Lichtscheidl. 2019. Strontium in the environment: Review about reactions of plants towards stable and radioactive strontium isotopes. Sci. Total Environ. 653:1458-1512, doi: https:// doi.org/10.1016/j.scitotenv.2018.10.312.

Chen, M., Y.L. Tang, J. Ao, and D. Wang. 2012. Effects of strontium on photosynthetic characteristics of oilseed rape seedlings. Russ. J. Plant Physiol. 59:772-780, doi: https://doi. org/10.1134/S1021443712060052.

Crystalmaker. n.d. Elements, atomic radii and the periodic radii. 11 Sept. 2015. < http://www. crystalmaker.com/support/tutorials/crystalmaker/ atomic-radii/index.html $>$.

Ermakov, V., J. Bech, U. Gulyaeva, S. Tyutikov, V. Safonov, V. Danilova, and N. Roca. 2020. Relationship of the mobile forms of calcium and strontium in soils with their accumulation in meadow plants in the area of Kashin-Beck endemia. Environ. Geochem. Health 42:159-171, doi: https:// doi.org/10.1007/s10653-019-00323-5.

Garty, J., R. Ronen, and M. Galun. 1985. Correlation between chlorophyll degradation and the amount of some elements in the lichen Ramalina duraei (De Not). Jatta. Environ. Exp. Bot. 25:67-74, doi: https://doi.org/10.1016/0098-84 72(85)90049-8.

Guillén, J. 2018. Factors influencing the soil to plant transfer of strontium, p. 19-31. In: D.K. Gupta and C. Walther (eds). Behaviour of strontium in plants and the environment. Springer International Publishing AG, Cham, Switzerland, doi: https://doi.org/10.1007/978-3-319-66574-0_2.

Gupta, D.K., U. Deb, C. Walther, and S. Chatterjee. 2018a. Strontium in the ecosystem: Transfer in plants via root system, p. 1-18. In: D.K. Gupta and C. Walther (eds.). Behaviour of strontium in plants and the environment. Springer International Publishing AG, Cham, Switzerland, doi: https://doi.org/10.1007/978-3-319-66574-0_1.

Gupta, D.K., S. Wolfgang, S. Georg, and W. Clemens. 2018b. Radiostrontium transport in plants and phytoremediation. Environ. Sci. Pollut. R. 25:29996-30008, doi: https://doi.org/10.1007/ s11356-018-3088-6.

Heuck, S., U.C. Gerstmann, B. Michalke, and U. Kanter. 2010. Genome-wide analysis of caesium and strontium accumulation in Saccharomyces cerevisiae. Yeast 27:817-835. <http:// doi.wiley.com/10.1002/yea.1780>.

Hodges, D.M., J.M. DeLong, C.F. Forney, and R.K. Prange. 1999. Improving the thiobarbituric acidreactive-substances assay for estimating lipid peroxidation in plant tissues containing anthocyanin and other interfering compounds. Planta 207:604 611, doi: https://doi.org/10.1007/s004250050524.

Höllriegl, V. and H.Z. München. 2011. Strontium in the environment and possible human health effects, p. 268-275. Encyclopedia of Environmental
Health, doi: https://doi.org/10.1016/B978-0-44452272-6.00638-3.

Ishida, N., M. Sugiura, F. Rappaport, T.L. Lai, W. Rutherford, and A. Boussac. 2008. Biosynthetic exchange of bromide for chloride and strontium for calcium in the photosystem II oxygen-evolving enzymes. J. Biochem. 283:13330-13340, doi: https://doi.org/10.1074/jbc.M710583200.

Jiang, D.C., Z.Q. Liu, X.X. Song, L. Gong, F.D. Wang, N.W. Qiu, and J.W. Gao. 2018. The photosynthetic characteristics of Chinese cabbage under calcium deficiency. Plant Physiol. J. 54:973-982, doi: https://doi.org/10.13592/j. cnki.ppj.2018.0176.

Kartosentono, S., A. Nuraida, G. Indrayanto, and N.C. Zaini. 2001. Phytoremediation of $\mathrm{Sr}^{2+}$ and its influence on the growth, $\mathrm{Ca}^{2+}$ and solasodine content of shoot cultures of Solanum laciniatum. Biotechnol. Lett. 23:153-155, doi: https://doi.org/10.1023/A:1010347914834.

Li, M., X.T. Xie, R.H. Xue, and Z.L. Liu. 2006. Effects of strontium-induced stress on marine microalgae Platymonas subcordiformis (Chlorophyta: Volvocales). Chin. J. Oceanology Limnol. 24:154-160, doi: https://doi.org/10.1007/BF02842815.

Moyen, C. and G. Roblin. 2010. Uptake and translocation of strontium in hydroponically grown maize plants, and subsequent effects on tissue ion content, growth and chlorophyll $\mathrm{a} / \mathrm{b}$ ratio: Comparison with $\mathrm{Ca}$ effects. Environ. Exp. Bot. 68:247-257, doi: https://doi.org/10.1016/j. envexpbot.2009.12.004.

Moyen, C. and G. Roblin. 2013. Occurrence of interactions between individual $\mathrm{Sr}^{2+}$ - and $\mathrm{Ca}^{2+}$. effects on maize root and shoot growth and $\mathrm{Sr}^{2+}$, $\mathrm{Ca}^{2+}$ and $\mathrm{Mg}^{2+}$ contents, and membrane potential: Consequences on predicting $\mathrm{Sr}^{2+}$-impact. J. Hazard. Mater. 260:770-779, doi: https://doi. org/10.1016/j.jhazmat.2013.06.029.

Nielsen, S.P. 2004. The biological role of strontium. Bone 35:583-588, doi: https://doi.org/ 10.1016/j.bone.2004.04.026.

Ozgen, S., J.S. Busse, and J.P. Palta. 2011. Influence of root zone calcium on shoot tip necrosis and apical dominance of potato shoot: Simulation of this disorder by ethylene glycol tetra acidic acid and prevention by strontium. Hort. Sci. 46(10): 1358-1362, doi: https://doi.org/10.21273/HORT SCI.46.10.1358.

Piñeros, M.A. and M. Tester. 1995. Characterization of a voltage-dependent $\mathrm{Ca}^{2+}$-selective 
channel from wheat roots. Planta 195:478-488, doi: https://doi.org/10.1007/BF00195704.

Porra, R.J. 2002. The chequered history of the development and use of simultaneous equations for the accurate determination of chlorophylls a and b. Photosynth. Res. 73:149156, doi: https://doi.org/10.1023/A:1020470 224740 .

Sasmaz, A. and M. Sasmaz. 2009. The phytoremediation potential for strontium of indigenous plants growing in a mining area. Environ. Exp. Bot. 67:139-144, doi: https://doi.org/10.1016/j. envexpbot.2009.06.014.

Sowa, I., M. Woijciak-Kosior, M. Strzemski, S. Dresler, W. Szwerc, T. Blicharski, G. Szymczak, and R. Kocjan. 2014. Biofortification of soy (Glycine $\max (\mathrm{L}$.$) Merr.) with strontium ions. J.$
Agr. Food Chem. 62:5248-5252, doi: https:// doi.org/10.1021/jf501257r.

Stirbet, A. and Govindjee. 2011. On the relation between the Kautsky effect (chlorophyll a fluorescence induction) and Photosystem II: Basics and applications of the OJIP fluorescence transient. J. Photochem. Photobiol. B 104:236-257, doi: https://doi.org/10.1016/j.jphotobiol.2010.12.010.

Sun, Y., Z.W. Zhang, and S.Q. Wang. 2018. Study on the bactericidal mechanism of atmosphericpressure low-temperature plasma against Escherichia coli and its application in fresh-cut cucumbers. Molecules 23(4):975, doi: https:// doi.org/10.3390/molecules23040975.

Sytar, O., P. Kumari, S. Yadav, M. Brestic, and A. Rastogi. 2019. Phytohormone priming: Regulator for heavy metal stress in plants. J. Plant Growth
Regul. 38:739-752, doi: https://doi.org/10.1007/ s00344-018-9886-8.

Wang, D., X.X. Zhang, X.G. Luo, and Y.L. Tang. 2015. Phytoextraction ability of Amaranthus mangostanus L. from contaminated soils with Cs or Sr. J. Bioremediat. Biodegrad. 6:277, doi: https://doi.org/10.4172/2155-6199.1000277.

Zhang, W.R., Z. Kang, Q. Wang, N.W. Qiu, M. Chen, and F. Zhou. 2020. The biological effects of strontium $\left({ }^{88} \mathrm{Sr}\right)$ on Chinese cabbage. Plant Soil Environ. 66:1-6, doi: https://doi.org/ 10.17221/108/2020-PSE.

Zheng, G.L., R. Pemberton, and P. Li. 2016. Bioindicating potential of strontium contamination with Spanish moss Tillandsia usneoides. J. Environ. Radioact. 152:23-27, doi: https://doi.org/10.1016/ j.jenvrad.2015.11.010. 